\title{
インドネシア人日本語学習者におけるメタ言語意識を利用した連 体修飾節の習得研究 \\ Study on Acquisition of Japanese Adnominal Clauses Using Metalanguage Awareness in Indonesian Learners
}

\author{
Samsul Maarif \\ Studies in Japanese Language and Culture, Graduate School of Language and Culture \\ Osaka University, Osaka, Japan \\ samsulmaarifhasjim@gmail.com
}

\begin{abstract}
A B S T R A C T
The theoretical research of Japanese linguistics is diverse. However, applying such research theory to Japanese language education does not necessarily help learners' understanding. The purpose of this research is to concretely present the problems that arise from the gap between theory and practice in Japanese language research and Japanese language education. In this study, we examine the effect of the theoretical explanation of the Japanese adnominal clause on the learners' understanding. We selected 10 second-year university Japanese learners as research subjects. They were selected because second-year learners already learn the adnominal clause. The adnominal clause was chosen because it has a considerably simple construction to check whether the learners can comprehend the meaning from those simple constructions. Since the theoretical explanation of linguistics is difficult for learners to understand, we gave a lesson using the learners' awareness of language called "metalanguage awareness." By using metalanguage awareness, learners are guided to understand the meaning through the comprehension of its grammatical construction using linguistic terms both in Japanese and their native language, which is Indonesian. As a result, it was found that even though adnominal clause construction is simple, the understanding of the meaning is not that simple. The understanding of adnominal clauses depends on the understanding of more basic learning items of "particles" and "clauses", which learners still can't grasp. We conclude that introducing such dependency in focus on form teaching method has the advantage for the teacher to check the degree of learners' understanding. In this study, the adnominal clause can be used to check whether learners have fully understood the concept and usage of "particles" and "clauses" in Japanese. Since both concepts are very basic, it is important to take a step back and re-explain both concepts and usage so learners can use them correctly in the future.
\end{abstract}

$$
\text { K E Y W O R D S }
$$

Applied Cognitive Linguistics; Japanese Adnominal Clause; Metalanguage awareness

A R T I C L E I N F O

First received: 12 July $2021 \quad$ Final proof accepted: 10 October 2021

Available online: 19 December 2021 


\section{はじめに}

日本語に関する言語学の理論的研究テーマは多 岐にわたる。しかし、そのような研究の理論を 日本語教育に応用寸ることが、必ずしも学習者 の理解を助けることにはならない。本研究の目 的は日本語研究と日本語教育における理論と実 践の乘離から生じる問題を具体的に提示するこ とである。Achard (2008) では最も一般的な問 題は言語学研究の成果を言語教育に応用させな いという批判がある。一方、言語教育からする と、言語学研究の成果は必ずしも学習者に役に 立つとは限らず、場合によっては混乱させてし まうこともあると述べている。

本研究は認知言語学を日本語教育場面に応用 させ、言語教育と言語学研究の間に懸け橋とな る立場にある。

Serrano (2011)ではメタ言語支持が第二言語取 得の分野に議論され、メタ言語的支持による学 習者の知識とパフォーマンスへの影響について 研究を行った。その結果、英語所有詞の教授に おいて、メタ言語的な支持はメ夕言語的な知識 と口頭産出にいい効果があったということが分 かった。

本研究の実験では連体修飾節の「内の関係」

と「外の関係」という言語学の理論的説明を授 業で行うことが学習者の理解にどのような効果 をもたらすかについて検討する。言語学の理論 的な説明は学習者にとって理解しづらいため、

「メタ言語意識」という学習者の言語への意識 を利用する授業を行った。「メタ言語意識」を 利用することで学習者の連体修飾節の理解への 手助けになるかどうかを授業前後に学習者を対 象に実施する試験の結果に基づいて検討した。

連体修飾節に関寸る項目は初級の段階で導入 される。例として「カレーライスを食べたい」 「お母さんが作りました」のような二つの文か ら「お母さんが作ったカレーライスを食べたい」 という文を作る練習が挙げられる（『学ぼう！ にほんご初級 1』)。その後の課では連体修飾 節に関する項目はほぼ触れられていない。

連体修飾節は一見シンプルな文法項目だが、 実際は主名詞と修飾節との関係を適切に理解し なければ意味を取り違えてしまう可能性がある 項目である。例えば、日本語能力試験の読解な どで間違った解釈をしてしまうと不正解の選択 肢を選びかねない。このように、日本語の連体
修飾節はシンプルだが重要な項目でもあるため 本実験の対象として選ばれた。

本実験はインドネシアの大学の日本語学科の 2 年生 10 人を対象とし、「メ夕言語」を意識さ せるグループとそうでないグループに分けた。

「メタ言語」を意識させるグループの方がより 良い成績をあげると予測した。しかし、実験の 結果、「メタ言語」を意識させたグループは連 体修飾節のテストでは好成績を残したものの、 助詞の役割や節の概念などの連体修飾節に関わ る文法項目の理解が十分でないことが分かった。

\section{先行研究}

\section{関係節化の可能性の階層（Noun Phrase Accessibility Hierarchy)}

関係節化の可能性の階層 (Noun Phrase Accessibility Hierarchy : 以下 NPAH）とは Keenan \& Comrie（1977）が提唱した関係節化のしやす さの序列である。50 以上の言語の類型学的調査 を行った結果、以下の関係節化のしや寸さの序 列が分かった。

主語（SU）>直接目的語（DO）>間接目

的語 ( IO ) > 前置詞の目的語 $(\mathrm{OP})>$ 所有

格 (GEN) > 比較級の目的語 (OCOMP)

ここでは「>」マークは「より可能性が高い」 という意味を表している。つまり、「主語」は 「直接目的語」よりも関係節化する可能性が高 いということである。よって、この序列では左 に行けば行くほどより関係節化しやすいという ことである。この NPAH は階層（Hierarchy）を 表しているので、ある言語が「間接目的語」を 関係節化できる場合、その左の「直接目的語」 と「主語」も関係節化することができるという ことである。また、この序列は関係節化のしや すさを表すので、左に行けば行くほど出現頻度 も高くなる。

NPAH はもともと類型論的研究であるが、言 語習得に関しては触れていない。しかし、その 類型論的な背景があるからこそ第二言語習得へ の応用、さらには、学習者の言語学習を容易に する方策につながる可能性が期待される。

齋藤（2002）では、第二言語習得と NPAHの 関連性についてのさまざまな研究がまとめられ ている。その研究では、主に以下の 2 点につい て述べられている。まず第二言語習得の過程が 
NPAH の序列通りになっているのか、そして、 NPAH の序列内のある項目を習得することが、 その下位項目を習得することにつながるのか、 ということである。これらのさまざまな研究は、 第二言語習得においてもほとんどNPAH の序列 通りに習得が進むという結果を表している。

\section{内の関係と外の関係}

日本語の連体修飾（名詞修飾）には、主名詞と 修飾節との関係を英語の「who, whom, whose」、 インドネシア語の「yang」などのような関係代 名詞で表さない。

（1）さんまを焼く男

（2）さんまを焼く匂い

例（1）では主名詞「男」と修飾節「さんま を焼く」の関係は「男がさんまを焼く」という ガ格で成立する。つまり、「男」は「さんまを 焼く」の主語である。一方、例（2）では、主 名詞「匂い」と修飾節「さんまを焼く」との関 係は「*匂い\{が・を・で・に\}さんまを焼く のように格助詞で成立しない。寺村（1975）は、 日本語の連体修飾の主名詞と修飾節の関係が例

(1) のように、格助詞で成立するものを「内 の関係」と呼び、例（2）のように格助詞で成 立しないものを「外の関係」と呼んでいる。

寺村（1975）では「外の関係」を「内容補充 的修飾」とも呼び、さらに、例（3）の「ふつ う内容補充」と例（4）の「相対的補充」に分 けている。

（3）選挙に出る考え

（発話・思考の内容）

（4）たばこを買ったおつり

（たばこを買った代金のおつり）

このような「外の関係」はほかの言語では関 係節で表されにくく、日本語特有の表現である。 そのため「外の関係」の習得は学習者にとって 困難である（寺村 1980）。

\section{メタ言語知識}

Azarola（2013）は、社会的な交流による知識 の発達について述べている Vygotsky と同じ立場 であり、「メタ言語知識」はコミュニケーショ ン活動の目的を概念化する道具として第二言語 の発達に関連すると述べている。そのため、
「メタ言語知識」を利用するにあたっては以下 の三つのポイントが重要であると述べている。

- 文法の指導目標は概念化する能力の育成 でもある。

・文法の指導において意味・語用論的な要 素を一貫した方法で提示するのが重要で ある。

・「メタ言語知識」は言語的思考をするた めの道具として文法の説明と文型の練習 に利用するだけではなく、概念化が必要 なコミュニケーションやタスクをすると きにも利用するべきである。

Azarola（2013）は学習者に正しく提示し、 操作すれば、「メタ言語知識」が第二言語学習 者の思考活動の一部となると述べている。そし て、その思考活動とコミュニケーション行為を 統合したタスクに「メタ言語知識」を応用する 実験を行った。その実験では学習者にコミュニ ケーション行為を意識させ、なぜそこにその文 法項目を選んだのか学習者自身に説明させるの が狙いだった。

実験を行う前に学習者はスペイン語のアスペ クトについて事前に教えられた。実験はコミュ ニケーションと概念化するタスクの形式で行わ れた。コミュニケーション・タスクでは Thanksgivingの休暇中の出来事について、教師に アドリブで話させ、それを録音した。教師は、 話すとき必ずスペイン語のアスペクトを利用す るように指示されていた。そして、学生にその 音声を文字化させた。概念化するタスクでは文 字化した話から 8 つの発話を分析させた。その 分析では話の流れにおいて語彙、文法的な要素 がどのように関連するのか。また、自分が伝え たいことが使用されるアスペクトで適切に表せ るのかを説明しなければならない。実験の結果、 スペイン語のアスペクトを正しく使える学習者 が、概念化された難しい文法項目を自分自身に 説明することで文法の理解度や正用率が高まっ たということが分かった。

結論として、Azarola（2013）では「メタ言 語知識」を有効な言語思考として利用するには、 文法をより概念的な項目として指導するべきで あると述べている。そのため教師には、単純な 文法のルールの説明だけにとどまらず、より良 い語彙、語用論的な文法の説明が求められる。 重要なのは、コミュニケーションの場における 学習者の言葉選びに、しっかりとした概念的な 理解が伴っているということである。 
Serrano (2011) では英語を第二言語とする小学 生を対象として、英語の所有限定詞の授業でメ 夕言語的な支持を利用し、メ夕言語知識と口頭 産出との影響を検証した。その結果として、メ 夕言語的な支持には向き不向きな学生があった が、メタ言語的な支持はメタ言語的な知識と口 頭産出にいい効果があった。しかし、学生の知 識とパフォーマンスに重要な影響を与えるとは 言いえないと述べている。

本研究は Serrano (2011) の対象者と違って、 小学生ではなく、大学生であるため、知識とパ フォーマンスとの影響が期待できると考えた。

また、森内 (2016)では外国語教育において、 学習者のメタ言語能力を育成するためには書く 活動が重要だと述べている。しかし、その書く 活動で学生の誤りを訂正するという一般的な方 法では、学生が言語形式に注意しない傾向があ る。そのため、䛊りの訂正ではなく、メタ言語 的なフィードバックという方法で学生の注意を 意味から言語形式に移行させる必要がある。し かし、その方法には教師が学生の誤りを上手く 活用し、Focus on Form に気づかせる努力が必要 と述べている。

本研究では連体修飾節の内と外の関係におい て、主名詞を修飾節に戻す練習を通して、学習 者に Focus on Form 気づかせることを試みた。

\section{調査方法}

\section{実験の対象}

本研究ではパジャジャラン大学のインドネシア 人日本語学習者 10 名の 2 年生を対象として、 2021 年 4 月 10、16、17 日に実験を行った。実 験はメタ言語を意識させることによって連体修 飾節の理解を促進するという目的で行われたた め、対照群と実験群それぞれ 5 名のグループを 形成した。対照群と実験群を選ぶ方法に関して は実験前のテストの結果を利用した。以下表 1 が対象とする学生のデータである。
表 1. 被験者のデータ

\begin{tabular}{|c|c|c|c|c|c|}
\hline \multicolumn{3}{|c|}{ 対照郡 } & \multicolumn{3}{|c|}{ 実験群 } \\
\hline 学生 & $\begin{array}{c}\text { 学習歴 } \\
\text { (年) }\end{array}$ & $\begin{array}{c}\text { 能力 } \\
\text { 試験 }\end{array}$ & 学生 & $\begin{array}{c}\text { 学習歴 } \\
\text { (年) }\end{array}$ & $\begin{array}{c}\text { 能力 } \\
\text { 試験 }\end{array}$ \\
\hline $\mathrm{K}$ & 2 & $\mathrm{~N} 5$ & $\mathrm{Z}$ & 3 & $\begin{array}{c}\mathrm{N} 5 \\
\text { 不合 } \\
\text { 格 }\end{array}$ \\
\hline $\mathrm{AD}$ & $>3$ & $\mathrm{~N} 5$ & $\mathrm{R}$ & 2 & ない \\
\hline $\mathrm{B}$ & $>3$ & $\mathrm{~N} 5$ & $\mathrm{~F}$ & 2 & ない \\
\hline $\mathrm{M}$ & $>3$ & $\mathrm{~N} 5$ & $\mathrm{AR}$ & 2 & ない \\
\hline $\mathrm{AB}$ & $>3$ & $\mathrm{~N} 2$ & $\mathrm{D}$ & 2 & ない \\
\hline
\end{tabular}

\section{実験の流れ}

以下実験の流れを述べる：

1. 2021 年 3 月 16 日〜 月 5 日まで被験者を募集 した。

2. 2021 年 4 月 10 日、実験前のテストを行った。

3. 2021 年 4 月 16 日、対照群の授業を行い、テ ストを課して翌日に提出させた。

4. 2021 年 4 月 17 日、実験群の授業を行い、テ ストを課して翌日に提出させた。

連体修飾節は 1 年生ですでに習った項目であ るため、実験授業前半では主に連体修飾節につ いて復習させた。後半では内の関係と外の関係 について教えた。実験は対照群と実験群に分け、 対照群ではそのままの内容、つまり、日本語の 連体修飾節のみについて教えた。一方、実験群 ではメタ言語を意識させるためにインドネシア 語の関係代名詞 yang の役割と有無についても気 付かせるような内容とした。

実験前後に被験者に連体修飾を中心とするテ ストを受けさせた。テストは 3 つの問題形式か ら構成された。以下がそのテスト形式である：

- 問 1 では内の関係を表寸文に○、外の関係 を表す文にメを付ける形式で内の関係と外

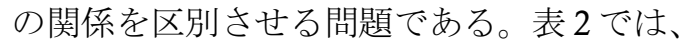
網掛けのものが内の関係である。

- 問 2 では問 $1 \bigcirc を$ 付けたものに主名詞を修 飾節に戻す文に書き換える問題である。

- 問 3 では連体修飾を含む日本語の文をイン ドネシア語に訳させる問題である。 
表 2. 問 1 の問題

\begin{tabular}{|c|c|c|c|}
\hline \multicolumn{2}{|r|}{ 実験前テスト } & \multicolumn{2}{|r|}{ 実験後テスト } \\
\hline 1 & 姉は高校で日本語を教える仕事をしています。 & 1 & 海外で人気なアニメを作った監督が亡くなりました。 \\
\hline 2 & 店員が怒りを感じるお客さんの言葉について調べてみた。 & 2 & 差別に聞こえる政治家のスピーチが問題になった。 \\
\hline 3 & この小説では、友達にだまされる辛さがうまく書かれている。 & 3 & 自転車を置いた所を忘れてしまいました。 \\
\hline 4 & パンを買ったおつりでジュースを買った。 & 4 & 旦本語を正しく発音する練習をしましょう。 \\
\hline 5 & たくさんの小説を書いた作家がテレビに出ている。 & 5 & 学校で花子さんがお化けを見た噂が広まっている。 \\
\hline 6 & 水をまいた場所はどこですか。 & 6 & その女性は津波で子供がしくなった悲しみを話しました。 \\
\hline 7 & 田中さんから聞いた話はいつも面白かった。 & 7 & インターネットで広まる噂には嘘が多いです。 \\
\hline 8 & このアニメはロボットが人間の女の子を好きになる話です。 & 8 & この洗剤はコーヒーを拭いた污れもきれいにします。 \\
\hline 9 & 日本ではお風呂に入る前に体を洗う習慣がある。 & 9 & 空を飛んでいる鳥を捕まえた。 \\
\hline 10 & 高速道路を走っているバイクが警察に止められた。 & 10 & 日本では求正月に田舎に帰る文化がある。 \\
\hline
\end{tabular}

表 3. 問 1 の正答

\begin{tabular}{|l|l|l|c|}
\hline \multicolumn{2}{|c|}{ 実験前テスト } & \multicolumn{2}{c|}{ 実験後テスト } \\
\hline 2 & お客さんの言葉に占員さんが怒りを感じる。 & 1 & $($ その) 監督が海外で人気なアニメを作った。 \\
\hline 5 & その作家がたくさんの小説を書いた。 & 2 & 政治家のスピーチが差別に聞こえる。 \\
\hline 7 & 田ささんから (その) 話を聞いた。 & 7 & $($ その) 噂がインターネットで広まる。 \\
\hline 10 & バイクが高速道路を走っている。 & 9 & 鳥が空を飛んでいる。 \\
\hline
\end{tabular}

以下が授業で行ったことである：

・まず、連体修飾節について振り返る内容を 説明する。

一実験群のみ：連体修飾と対応とするインド ネシア語の関係代名詞 yang について導入し て教える。「yang」の有無によって「yang」 の役割を気づかせる。（メタ言語を意識さ せる)

-「どんな本ですか?」「図書館で借りた」 $\rightarrow$ 「図書館で借りた本」というパターンで 連体修飾を練習する。

・連体修飾節内には「は」 $\rightarrow$ 「が」になる、 主名詞に係るものは辞書形であるというル ールを説明する。

-「内の関係」と「外の関係」を説明する。 「内の関係」の場合では主名詞が修飾節の 格助詞を使って関係を表すことができる。
・実験群のみ：「内の関係」のほとんどは関 係代名詞「yang」で表せることを説明する。

-「内の関係」と「外の関係」を区別する。× 問題で練習する。

・「内の関係」の主名詞を修飾節に戻す練習 をする。

\section{調査結果と分析}

本研究は問 1 と問 2 の結果を中心に分析を行う。 まず、対照群と実験群の実験前後のテスト結果 を見ていく。 


\section{授業前後テスト問 1 と 2 の結果}

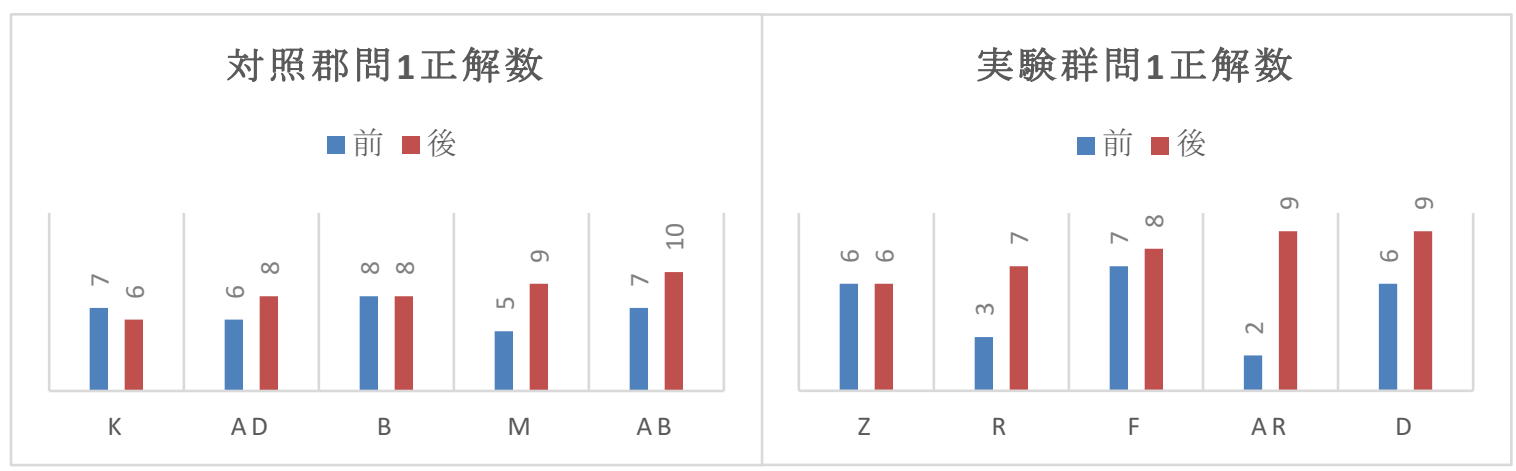

図 1. 対照群と実験群における前後テストでの問 1 の正解数

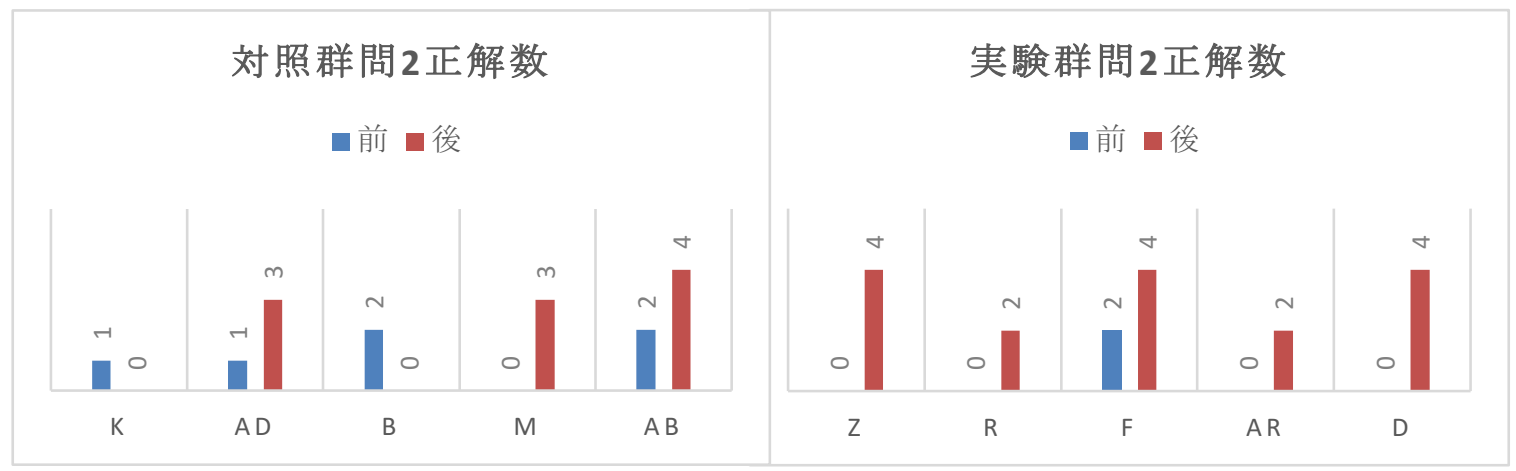

図 2. 対照群と実験群における前後テストでの問 2 の正解数

以上の図 1 と図 2 では対照群と実験群の問 1 と問 2 での正解数を表している。全体的には両方とも 実験後のテストではよくなったが、対照群の対象 群の平均正解数が 1.8 問に増えたのに比べ、実験 群は 3 問に増えた。特に AR さんが最も伸びたこ とが分かった。また、実験群の問 2 の正解数も対 照群を上回っている。正解数の結果を単純にみる と「メタ言語意識」を通して言語学の理論的な観 点が理解の手助けになるといえる。しかし、それ ぞれの学習者がどの問題で間違っているのか、ま た授業後のテストでどう変わったかという観点で 見るとその結論を留保せざるを得ない。

以下の表 3 と表 4 で赤色の網掛は問 1 の誤答分 布を表している。対照群 $\mathrm{AB}$ さんの授業後テスト が満点になったのは、すでに能力試験 N2 に合格 しているという理由がある。一方、他の学習者は
表 4 （授業後テスト）の誤答分布を表 3（授業前 テスト）と比べると、誤答分布はばらついている。 実験群の AR さんと Dさんが表 4 （授業後テス 卜）で間違っているところは、表 3 （授業前テス

ト）でも同じタイプの問題である。 $\mathrm{Z}$ さん、 $\mathrm{R}$ さ ん、と F さんは表 4 （授業後テスト） と表 3（授 業前テスト）で間違っているところに大きなばら つきがあり、対照群の $\mathrm{AD}$ さんと $\mathrm{B}$ さんにも同じ 様子がみられる。そして、表 4 (授業後テスト) のほとんどの誤答は「外の関係」だということの 判断ミスであることが分かつた。つまり、外の関 係では主名詞と修飾節の関係は格助詞で表せない はずだが、学習者は表せると思ってしまったので ある。その原因は格助詞の役割や使い方をまだ十 分に理解していないからだと考えられる。 
表 3. 授業前テスト問 1 の誤答分布

\begin{tabular}{|c|c|c|c|c|c|c|c|c|c|c|c|c|c|c|c|}
\hline \multirow{2}{*}{ 授業前 } & \multirow{2}{*}{ 番号 } & \multirow{2}{*}{ 問題 } & \multirow{2}{*}{ 正解 } & \multirow{2}{*}{ タイプ } & \multicolumn{5}{|c|}{ 対照群 } & \multicolumn{5}{|c|}{ 実験群 } & \multirow{2}{*}{$\begin{array}{l}\text { 誤 } \\
\text { 答 } \\
\text { 数 }\end{array}$} \\
\hline & & & & & K & $A D$ & B & M & $A B$ & $\mathrm{Z}$ & $R$ & $\mathrm{~F}$ & AR & D & \\
\hline \multirow{10}{*}{ 問題 1} & 1 & 姉は高校で日本語を教える仕事をしています。 & $x$ & 内容 & 0 & O & O & O & $x$ & 0 & 0 & $x$ & O & O & 8 \\
\hline & 2 & 店員が怒りを感じるお客さんの言葉について調べてみた。 & O & に格 & O & $x$ & O & $\times$ & $\bigcirc$ & $\times$ & $x$ & O & $x$ & O & 5 \\
\hline & 3 & この小説では、友達にだまされる辛さがうまく書かれている。 & $x$ & 付随（結果） & $x$ & O & $x$ & $x$ & $x$ & $x$ & $x$ & $x$ & O & $x$ & 2 \\
\hline & 4 & パンを買ったおつりでジュースを買った。 & $x$ & 付随（結果） & $x$ & $x$ & O & O & O & $x$ & 0 & $x$ & O & $x$ & 5 \\
\hline & 5 & たくさんの小説を書いた作家がテレビに出ている。 & $\mathrm{O}$ & が格 & O & $\bigcirc$ & ○ & $x$ & $\bigcirc$ & 0 & O & O & $x$ & $x$ & 3 \\
\hline & 6 & 水をまいた場所はどこですか。 & $x$ & 相対 & O & $x$ & $x$ & $x$ & $x$ & $x$ & 0 & $x$ & 0 & 0 & 4 \\
\hline & 7 & 田中さんから聞いた話はいつも面白かった。 & O & を格 & 0 & O & ○ & O & O & $x$ & $x$ & ○ & $x$ & O & 3 \\
\hline & 8 & このアニメはロボットが人間の女の子を好きになる話です。 & $x$ & 内容 & O & O & $x$ & $x$ & O & $x$ & $x$ & O & O & 0 & 6 \\
\hline & 9 & 日本ではお風呂に入る前に体を洗う習慣がある。 & $x$ & 内容 & $x$ & $x$ & $x$ & $x$ & O & $\times$ & 0 & O & $x$ & $\times$ & 3 \\
\hline & 10 & 高速道路を走っているバイクが警察に止められた。 & O & が格 & $O$ & ○ & ○ & $x$ & $\bigcirc$ & $x$ & $x$ & $x$ & O & O & 4 \\
\hline & & & & 誤答数 & 3 & 4 & 2 & 5 & 3 & 4 & 7 & 3 & 8 & 4 & \\
\hline
\end{tabular}

表 4. 授業後テスト問 1 の誤答分布

\begin{tabular}{|c|c|c|c|c|c|c|c|c|c|c|c|c|c|c|c|}
\hline \multirow[b]{2}{*}{ 授業後 } & \multirow[b]{2}{*}{ 番号 } & \multirow[b]{2}{*}{ 問題 } & \multirow[b]{2}{*}{ 正解 } & \multirow[b]{2}{*}{ タイプ } & \multicolumn{5}{|c|}{ 対照群 } & \multicolumn{5}{|c|}{ 実験群 } & \multirow{2}{*}{$\begin{array}{l}\text { 誤 } \\
\text { 答 } \\
\text { 数 }\end{array}$} \\
\hline & & & & & $\mathrm{K}$ & $A D$ & B & M & $A B$ & $Z$ & $\mathbf{R}$ & $F$ & AR & D & \\
\hline \multirow{10}{*}{ 問題1 } & 4 & 旦本語を正しく発音する練習をしましょう。 & $x$ & 内容 & 0 & $x$ & $\times$ & $x$ & $x$ & O & $x$ & O & $x$ & $x$ & 3 \\
\hline & 2 & 差別に聞こえる政治家のスピーチが問題になった。 & O & が格 & O & O & 0 & $x$ & ○ & O & 0 & O & O & $\mathrm{O}$ & 1 \\
\hline & 6 & その女性は津波で子供が亡くなった悲しみを話しました。 & $x$ & 付随（結果） & $\times$ & $x$ & O & $x$ & $x$ & O & 0 & $x$ & $x$ & $x$ & 3 \\
\hline & 8 & この洗剤はコーヒーを拭いた污れもきれいにします。 & $x$ & 付随（結果） & $x$ & O & $x$ & $x$ & $x$ & $x$ & $x$ & $x$ & $x$ & $x$ & 1 \\
\hline & 1 & 海外で人気なアニメを作った監督が亡くなりました。 & $\mathrm{O}$ & が格 & 0 & O & $\bigcirc$ & 0 & $\bigcirc$ & $O$ & 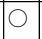 & $\bigcirc$ & O & O & 0 \\
\hline & 3 & 自転車を置いた所を忘れてしまいました。 & $x$ & 相対 & 0 & $x$ & $x$ & $x$ & $x$ & O & $x$ & $x$ & $x$ & $x$ & 2 \\
\hline & 7 & インターネットで広まる噂には嘘が多いです。 & O & が格 & 0 & O & O & O & O & 0 & O & O & O & ○ & 0 \\
\hline & 5 & 学校で花子さんがお化けを見た噂が広まっている。 & $x$ & 内容 & 0 & O & $\times$ & $x$ & $x$ & 0 & O & ○ & O & O & 7 \\
\hline & 10 & 日本ではお正月に田舎に帰る文化がある。 & $x$ & 内容 & 0 & $x$ & 0 & $x$ & $x$ & $x$ & 0 & $x$ & $x$ & $x$ & 3 \\
\hline & 9 & 空を飛んでいる鳥を捕まえた。 & $\mathrm{O}$ & が格 & 0 & 0 & 0 & 0 & 0 & 0 & 0 & 0 & 0 & 0 & 0 \\
\hline & & & & 誤答数 & 4 & 2 & 2 & 1 & 0 & 4 & 3 & 2 & 1 & 1 & \\
\hline
\end{tabular}

\section{問 2 の誤答回答の分析}

授業前後テストの問 1 と問 2 の正答数からみる と実験群が良い結果を示している。しかし、そ れぞれの群が授業後に本当に理解しているのか を見るためにはどのような誤答をしているのか を分析しないといけない。それぞれの群におい て最も目立った誤答を見ていこう。

表 5 は、Z さんと $\mathrm{F}$ さんの実際の答えを示し たものである。これは、学習者が「内の関係」 と思い込み、主名詞を修飾節に戻そうとしたも のである。これはそもそも「外の関係」だから、 主名詞を修飾名詞に戻せない。それにもかかわ らず、学習者が無理やり格助詞を入れようとし、 結果的に非文の回答になった。
さらに、表 6 では実験群の K さんと Bさんは 問 1 が正しく「内の関係」として判断できたに もかかわらず、主名詞を修飾節に書き換えると きに格助詞の誤用がみられた。

$\mathrm{K}$ さんと Bさんの回答を見ると、格助詞の誤 用のほかに、どれが修飾節なのかが分からない という問題もあるようである。つまり、二人と も「節」の概念がよく理解していないと考えら れる。今までの連体修飾節の習得方法は「節」 の概念を取り入れないで二つの文を一つにする という練習で行われた。この方法は文法を考え ず、学生に負担をかけないという点ではいいか もしれないが、「節」の概念が十分に定着しな いという欠点があると考えられる。「節」の概 念を把握することで、文全体の意味をチャンク として理解しやすくなり、誤解を防ぐ役割があ ると考えられる。つまり「節」という言語学的 
な要素を意識させることが重要になってくる。 本研究では実験群において「節」の概念の説明
も取り入れたが、それが十分ではなかったと考 えられる。

表 $5 . \mathrm{Z}$ と $\mathrm{F}$ の授業後テスト問 2 の誤答回答

\begin{tabular}{|c|c|}
\hline$Z$ & \multicolumn{1}{|c|}{$F$} \\
\hline 練習で日本語を正しく発音する & 練習を日本語を正しく発音する \\
\hline 噂に花子さんがお化けを見た & 噂に花子さんがお化けを見た \\
\hline
\end{tabular}

表 6. K と B の授業後テスト問 2 の誤答回答

\begin{tabular}{|c|c|}
\hline $\mathrm{K}$ & B \\
\hline 海外で監督に人気なアニメを作ったが忙しいです。 & 海外で人気がアニメを監督が作った。 \\
\hline 差別にスピーチで聞こえる政治家が問題になった。 & 差別に聞こえるスピーチの政治家が問題になった。 \\
\hline インターネットで嘘の広まる噂が多いです。 & インターネットの壿に広まる。 \\
\hline 空を鳥の飛んでいるを捕まえた。 & 鳥が空を飛んでいるを捕まえた \\
\hline
\end{tabular}

\section{学習者の連体修飾習得に対するメタ 言語意識の効果}

授業後のテスト問 1 においてガ格で主名詞を戻 せる連体修飾節の正答率は上がった。しかし、 実際に問 2 でそれを文として戻すタスクにおい ては正答率が低くなり、問 1 とは逆の結果が生 じた。ではなぜ問 1 での正答率が高いにもかか わらず、問 2 ではガ格を利用する文をうまく答 えられなかったのだろうか。これにはおそらく Keenan \&Comrie (1977) が主張した NPAH (Noun Phrase Accessibility Hierarchy) の通り、主 語を表す関係代名詞が最も処理しや寸く、その ため、学習者が意味を中心に理解することがで きる問 1 のような問題においては正答率が高く なるという理由があると考えられる。しかし、 問 2 は意味よりも形式が中心になる問題である ため、問 1 で正解ができても問 2 ではうまくで きなかったのではないだろうか。

確かに連体修飾節を「内の関係」と「外の関 係」を区別し、さらに「内の関係」の主名詞を 戻すタスクは難易度が高く、学生も慣れていな いため授業後のテストの解答は望まれる内容と はやや乘離している。しかし、この結果から示 唆される、学習者が助詞という最も基本的な文 法項目を十分に理解していないという事実は、 より高度な文法の理解には基本的な文法理解が 不可欠であるということが改めて明らかとなっ た。

本実験はメタ言語意識を活性化することによ って連体修飾節の「内の関係」と「外の関係」 という言語学の理論的な項目を対象に行った。 そしてそこから、言語学の理論的な視点を日本
語学習に応用するとどのような問題やギャップ が見えるかという研究目的を背景に行った。そ の結果として、連体修飾節の「内の関係」と 「外の関係」を区別するタスクが「助詞」と 「節」というより基本的な学習項目に依存して いるという興味深い結果が得られた。

日本語学習において難しい項目を理解するには その前の項目を理解しないといけないという依存 関係があるのは当たり前のことだと考えられる。 しかし、このような依存関係はほとんどの教科書 では明示されていないので、教師は指導の過程で それを判断せざるを得ない。本研究の連体修飾節 の「内の関係」と「外の関係」を区別するタスク には、「助詞」と「節」という項目が依存するこ とは明らかである。このような観点を授業で導入 し、教師が Focus on Form の指導法として使用寸る ことを通して、学習者の理解の度合いを確認でき る。そこから教師が授業を進めるか、もう一度前 の授業に戻るか検討できるというメリットがある と考えられる。

\section{まとめと今後の課題}

本研究では連体修飾節という言語学の理論的な 観点から、「メタ言語」を意識させることが日 本語学習にどのように影響を与えるかについて 実験を行った。その結果、連体修飾節の理解は 「助詞」と「節」というより基本的な学習項目 の理解に依存することが分かった。このような 依存関係を実際に Focus on Form の指導法で導入 すると、教師が学習者の理解の度合いを確認す ることができるというメリットがある。しかし、 
本研究の被験者が主に日本語能力試験 N5 のレ ベルであり、またある特定の大学で行われてい るものであるため、本研究の結果は適用範囲が 狭い。異なる大学の学生、ないし、異なるレべ ルの学生を対象とすることで別の要因を明らか にできると考えられる。

また、本研究の実験で扱ったインドネシア 語の「メタ言語」を意識させる際には、インド ネシア語の名詞修飾の体系をより明らかにする 必要もある。また、制約の緩い日本語の連体修 飾節と比べて、インドネシア語の名詞修飾節は yang の有無と受け身文とのかかわりがあり、制 約が強い言語でもある。メ夕言語意識をさせな がら日本語の連体修飾を英語の関係代名詞を通 じて教えることも一つの方法だと考えられる。

\section{参考文献}

Achard, M. (2008). Grammatical Instruction in The Natural Approach: A Cognitive Grammar View. In Cognitive linguistics, second language acquisition, and foreign language teaching (165-194). De Gruyter Mouton.

Azarola, E. N. (2013). The Being and Becoming of Metalinguistic Knowledge: Rules and Categories of Grammatical Description as Functional Tools of The Mind. The metalinguistic dimension in instructed second language learning (221-242). Retrieved from Bloomsburry Collection.
Kawatu, Aditio M. D. (2016). Analisis Kesalahan Penggunaan Klausa Relatif Mahasiswa Program Studi Pendidikan Bahasa Jepang Universitas Negeri Manado (Unpublished master's thesis). Universitas Pendidikan Indonesia.

Keenan, E. \& Comrie, B. (1977). Noun phrase accessibility and universal grammar. Linguistic Inquiry, 8(1), 63-99. Retrieved from jstor.org.

Serrano, R. (2011). From metalinguistic instruction to metalinguistic knowledge, and from metalinguistic knowledge to performance in error correction and oral production tasks. Language Awareness, 20(1), 116. DOI: $10.1080 / 09658416.2010 .529911$

神澤克徳. (2018). 「連体修飾構文の認知言語学的研究」 『京都大学博士論文』。

齋藤浩美. (2002). 「連体修飾節の習得に関する研究 の動向」『言語文化と日本語教育』5, 45-69.

寺村秀夫. (1975). 「連体修飾のシンタクスとその意味 一その 1 一」『日本語・日本文化』4, 大阪外国 語大学留学生別科. 71-119.

寺村秀夫. (1980). 「名詞修飾部の比較」國廣哲彌編 『日英語 比較講座一文法二』大修館書店. 221260.

中島紀子. (2019).「日本語教科書における 連体修飾 節の例文分析」『大正大学研究紀要』104. 133150

日本語教育教材開発委員会. (2005).『学ぼう!にほ んご初級 1』東京, 専門教育出版.

森内悠佳子. (2016). 「外国語学習者のメ夕言語能力 についての考察」『フランス語フランス文化研 究』(22), 1-9. 